\title{
Introduction: Self-Translating, from Minorisation to Empowerment
}

Olga Castro, Sergi Mainer, and Svetlana Page ${ }^{1}$

Multilingualism, cultural awareness and ethnic diversity have become staple terms of both academic and political ideologies across Europe. Whether these features are promulgated via the EU guidelines for its member states or by globalisation and international trade deals for non-EU European countries, multilingualism is - and has been for centuries - one of the trademark features of European geographies. Be it within Europe or elsewhere, one of the aspects of multilingualism is a power differential between languages. Indeed, since various languages and cultures are rarely, if ever, of equal status in multilingual contexts, any encounter between them will inevitably contain some sort of underlining, constituent power. The visibility of power or, for that matter, its often deliberate invisibility - is demonstrated in and through translation, "one of the most representative paradigms of the clash between two cultures" (Álvarez and Vidal 1996b, 1). Yet to what extent is the (in)visibility of power demonstrated through self-translation - defined here as the translation of one's own work originally produced in a source language into a target language, with the specificity that the author-translator is competent in both? Not surprisingly, the question of power, and the impact of the power differential, has recently taken centre stage in the development of

\footnotetext{
${ }^{1}$ (C) The Author(s) 2017. O. Castro, Aston University, Birmingham, UK; S. Mainer, University of Edinburgh, Scotland, UK; S. Page, University of Birmingham, Birmingham

O. Castro et al. (eds.), Self-Translation and Power, Palgrave Studies in Translating and Interpreting, DOI 10.1057/978-1-137-50781-5_1
} 
Castro, Olga, Sergi Mainer and Svetlana Page. 2017. Introduction: Self-Translating, from Minorisation to Empowerment. In Self-Translation and Power: Negotiating Identities in Multilingual European Contexts, ed. Olga Castro, Sergi Mainer and Svetlana Page, 1-22. London: Palgrave.

translation studies as a discipline, most particularly in its descriptive branch. It is now time to explore how the issue of power relates to the specific practice of self-translation, itself an increasingly common activity and also an emerging academic subdiscipline.

\section{Steering the Power Turn}

Since the expression cultural turn was coined by Susan Bassnett and André Lefevere (1990) for the translation of literary works, translation is no longer understood as an objective and neutral linguistic shift from one language to another, but rather as a powerful act of mediation and transformation closely linked to existing power structures or counterpower activism within wider socio-political and cultural contexts. The cultural turn involves the incorporation of the all-encompassing cultural dimension, making language work as a parallel or interconnected system to culture instead of as an external referential entity. Translation is now inexorably culture-bound. Timely collections, such as Translation, Power, Subversion edited by Román Álvarez and África Vidal (1996a), added the term power to the axis of debate in translation studies by emphasising the necessity to scrutinise "the relationship between the production of knowledge in a given culture and its transmission, relocation, and reinterpretation in the target culture" $(1996 \mathrm{~b}, 1)$. As the two editors argued, this was obviously involved "with the production and ostentation of power and with the strategies used by this power in order to represent the other culture" $(1996 \mathrm{~b}, 1)$. The collection was therefore crucial in 
Castro, Olga, Sergi Mainer and Svetlana Page. 2017. Introduction: Self-Translating, from Minorisation to Empowerment. In Self-Translation and Power: Negotiating Identities in Multilingual European Contexts, ed. Olga Castro, Sergi Mainer and Svetlana Page, 1-22. London: Palgrave.

creating a long-lasting link between power and translation. Two decades later, the prevalence of Susan Bassnett's contributing words to that volume confirms the centrality of power to translation: "the study and practice of translation is inevitably an exploration of power relationships within textual practices that reflect power structures within the wider cultural context" (Bassnett 1996, 21).

Subsequently, in their influential volume Translation and Power (2002), Edwin Gentzler and Maria Tymoczko claimed that it was time for a new turn, as "the cultural turn in Translation Studies has become the power turn" (Tymoczko and Gentzler 2002, xvi). A number of reasons justified this new research angle. First, the need for emphasising that all translations necessarily involve different exertions of power, or in their own words, "the key topic that has provided the impetus for the new directions that translation studies have taken since the cultural turn is power" $(2002$, xvi). The asymmetrical relations between agents, actors and/or contexts inescapably permeate all translation projects, underlining the significance of investigating power. Indeed, the exploration of specific power relations in which translations are made is a necessary and fundamental starting point to get a better understanding of the polysemic nature and far-reaching effects of translations. As a consequence, the shifts occurring in our understanding of translation cannot be completely explained through culture itself, but rather in the power relations governing any culture, language or, more specifically, literary production, as demonstrated by André Lefevere's patronage system (1992). 
Castro, Olga, Sergi Mainer and Svetlana Page. 2017. Introduction: Self-Translating, from Minorisation to Empowerment. In Self-Translation and Power: Negotiating Identities in Multilingual European Contexts, ed. Olga Castro, Sergi Mainer and Svetlana Page, 1-22. London: Palgrave.

A second reason was the recognition that, in the cultural turn, power had been characterised as a monolithic entity, recurrently understood in absolutist ways as control and repression taking place in dichotomical situations of "powerful" vs. "powerless." Conversely, the power turn sought to redefine power as a more diversified entity where cultural representations and identities are negotiated in translation in line with the foucauldian maxim that "là où il y a pouvoir, il y a de la résistance" $(1976,123)$ [where there is power, there is resistance]. Similarly, and also in line with Michel Foucault (1995, 194), power is a "productive" or impartial force; thus, it can be deployed either oppressively or liberatingly. Power merely refers to the extent by which one group is able to limit (through direct control, influence or manipulation) the actions and activities of another group, and can be multidirectional and simultaneous within a society, from "top" to "bottom," "bottom" to "top" or sideways, from one peer group to another. Equating power with oppression no longer stands as the only valid interpretation. Either individually or - more effectively - collectively, power has also been exercised from the bottom throughout history, from Spartacus' first-century BC slave uprising to the Peasants' Revolt in England (1381) or to the more recent worldwide antiglobalisation movements and the Kurdish Revolution of current times. The application of this multi-layered understanding of power to translation studies highlights the agency of the translator in either perpetuating repression or challenging it. Not only does power encompass the definition of repression and control, but also the ability to resist and subvert such actions. Translation is not impartial, and can be used as an instrument for imposing hegemonic 
Castro, Olga, Sergi Mainer and Svetlana Page. 2017. Introduction: Self-Translating, from Minorisation to Empowerment. In Self-Translation and Power: Negotiating Identities in Multilingual European Contexts, ed. Olga Castro, Sergi Mainer and Svetlana Page, 1-22. London: Palgrave.

values, for legitimating the status quo, for removal of thoughts or behaviours which are not considered desirable and for producing knowledge in "favour" of the (repressive) power, often in subtle and invisible (thus, very effective) ways. Yet, it can also become an empowering activity through which translators deliberately opt for resistance practices at a specific historical time and in a given socio-historical situation, for example, by "subverting traditional allegiances of translation, interjecting their own worldviews and politics into their work" (Gentzler 2002, 197). This act of resistance against established values and norms, however, is not to be framed in a dualistic representation of power (a dichotomy between complete opposition and complete submission), but rather in shifting power dynamics that situate translators in blurred positions of hybridisation - power relations in translation are being constantly negotiated. In fact, it is not only translators who are empowered by this conceptualisation of power, but also any and all actors in the translation process: editors, publishers and importantly the target audience, creating a complex set of power struggles in the search to create, alter or condition meaning. This is the reason why the role of translators as agents of cultural and social change is inevitably inseparable from the multiplicity of tensions at different levels. Hence, studying the possibilities opened by these dynamic power relations and fluctuating identities becomes productive and pivotal to the understanding of translation processes. The translators' approach to their activity, the choices made while translating, will undoubtedly have an impact on the creation of knowledge about different cultures and languages: on the image created of the source text, the source language, the source culture and 
Castro, Olga, Sergi Mainer and Svetlana Page. 2017. Introduction: Self-Translating, from Minorisation to Empowerment. In Self-Translation and Power: Negotiating Identities in Multilingual European Contexts, ed. Olga Castro, Sergi Mainer and Svetlana Page, 1-22. London: Palgrave.

the text's impact on the target culture. When discussing power in selftranslation, all in all, it is therefore crucial to critically engage with the power turn as a way of delineating what the particularities of self-translation are when practised by author-translators in bilingual/multilingual contexts.

\section{Multilingualism and Power Dynamics in Europe}

This collection chooses to focus its attention on the European continent, defined broadly in terms of its geographies rather than its commonly narrow understanding of EU associated states. Conceptualised in this way, Europe's constant geopolitical and historical transformation from the Middle Ages to the present day offers a prolific intercultural and intracultural context to examine power relations with regards to the political, social, cultural and economic implications of self-translation. Indeed, the rhetoric of the mainstream academic and political ideologies endorses and even celebrates European linguistic diversity. Yet, these ideologies mainly account for the official languages of the nation-states; meaning that in practice other existing nonstate official and unofficial languages in Europe are left in the shadow. This is where this collection aims to bring some light by discussing the condition of Occitan in France (see Lagarde), of Basque and Catalan in Spain (see Hulme, Manterola and Ramis) or of Dutch in Belgium (see Grutman); and also by discussing often neglected spaces in European narratives, such as Switzerland (see Rickenbach) and Turkey (see Akbatur and Ozdemir), or 
Castro, Olga, Sergi Mainer and Svetlana Page. 2017. Introduction: Self-Translating, from Minorisation to Empowerment. In Self-Translation and Power: Negotiating Identities in Multilingual European Contexts, ed. Olga Castro, Sergi Mainer and Svetlana Page, 1-22. London: Palgrave.

migratory spaces where Italian-Arabic, Russian-French or Spanish-Ladino interactions take place (see Wilson, Holter and Ribgy, respectively).

Based on a selection of case studies, the collection offers a sufficiently wide canvas to represent a variety of the complex interconnections of multilingualism, power and self-translation happening in this heterogeneous region. As such, it illustrates how negotiations between hegemonic and minorised cultures take place in an increasingly multicultural and everchanging space. The complex European milieu offers an ideal ground for studying liquid identities owing to the current fluidity of travelling discourses. Due to continuous fluxes of migration and travel from different parts of the globe, the linguistic map of the continent has been changing and the European translation scene can no longer be confined to investigations of several hegemonic translation-intensive languages. This adds a new layer of analysis to hybridisation and to the formation of multifaceted identities.

By reaching past hegemonies and highlighting the unequal relationships between languages involved in self-translation, this collection wishes to disperse an existing perception of Europe as a monolithic cultural and/or political space still largely pertaining to postcolonial critique. While Europe has been traditionally regarded as the coloniser, this view is an essentialist conceptualisation of Europe that ignores the existing asymmetry and inequality of relations between peoples and languages within the continent (Cronin 1995, 85). In fact, there is a growing body of work investigating the similarities in terms of both features and processes that the European minorised languages/literatures share with those of the colonised 
Castro, Olga, Sergi Mainer and Svetlana Page. 2017. Introduction: Self-Translating, from Minorisation to Empowerment. In Self-Translation and Power: Negotiating Identities in Multilingual European Contexts, ed. Olga Castro, Sergi Mainer and Svetlana Page, 1-22. London: Palgrave.

nations (Cronin 1995 and 2003; Díaz Fouces 2005; Yurchuk 2013); a quick look at journals such as mTm: minor Translating major - major Translating minor is quite revealing in this regard. Therefore, it is possible to contend that within Europe, there are practices of intra-colonisation within multilingual nation-states.

The power dynamics within Europe has attracted various, often conflicting, terminologies that are in use in translation and world literature studies. One of the first in that regard is the notion of the "polysystem," developed by Itamar Even-Zohar $(1978,1990)$ through an analysis of European hegemonic and Russian literary examples. Not only did this theory introduce the notion of the polysystem in translation studies, but it also presented controversial terms describing the degrees of remoteness from the desirable hegemonic centre: "periphery," "semi-periphery" and "centre." While translation studies have had a mixed reaction to the proposed terminology when referred to "weak literatures," as "crude ... evaluative terms" (Bassnett 1998, 127) lacking "clarity regarding the vantage point from which the comments are made" (Hermans 1999, 109), world literature studies seem to be less dismissive of the terminology. In the world systems theory (see Wallerstein 1974 and 2004), "semi-peripheral" or "peripheral" are not regarded as evaluative terms and thus are in mainstream usage - a recent publication by the Warwick Research Collective's (2015) findings titled Combined and Uneven Development: Towards a New Theory of World-Literature is an illustrative example in this regard, as well as Pascale Casanova's (1999) notable work on the "World Republic of Letters." 
Castro, Olga, Sergi Mainer and Svetlana Page. 2017. Introduction: Self-Translating, from Minorisation to Empowerment. In Self-Translation and Power: Negotiating Identities in Multilingual European Contexts, ed. Olga Castro, Sergi Mainer and Svetlana Page, 1-22. London: Palgrave.

A number of authors, including some in this collection, use the term "minority" to describe the status of some European languages and literatures. While recognising its validity, as editors we have chosen to build on Gilles Deleuze and Félix Guattari's concept of "minor" literature (1986) and to favour the term "minorisation" instead, to refer to language and literatures placed in a less powerful or secondary position in power hierarchies. As argued by Donna Patrick $(2010,176)$, at the macrolevel a minorised language and literature lack status, prestige, diffusion, standardisation and a normalised functional use, in favour of another normalised entities; at the microlevel, a minorised language and literature lack recognition by speakers of the sociolinguistically dominant language, with users of the minorised entities generally conforming and ultimately adopting those dominant views. Thus, by suggesting the term "minorised" we are questioning precisely the fact that these language and literatures are placed in a secondary position in power hierarchies, but also highlighting the continual resistance which becomes their daily experience while co-existing alongside their competing hegemonic language(s).

Seen in this light, European minorised languages emerge as a locus for a postcolonial analysis of language politics in conflict. By way of example, the interactions between official state languages and both non-state official and unofficial languages within the same territory typically lead to diglossia, signifying a hierarchical relationship between languages. This tends to generate a series of cultural and linguistic tensions affecting the notions of hegemony, resistance, dominance, subversion and (inter-)dependency between literary polysystems. Indeed, the different bilingual "interliterary 
Castro, Olga, Sergi Mainer and Svetlana Page. 2017. Introduction: Self-Translating, from Minorisation to

Empowerment. In Self-Translation and Power: Negotiating Identities in Multilingual European Contexts, ed. Olga Castro, Sergi Mainer and Svetlana Page, 1-22. London: Palgrave.

communities" (Ďurišin 1984) developed around the non-state official languages as well as the unofficial languages are typically defined by an asymmetrical bilingualism or diglossia in relation to the official state languages.

In Casanova's terms, the unequal asymmetries between literary polysystems means that there are "dominating" and "dominated" literatures (1999). When exploring the exchanges between them through self-translation, we identify three scenarios: first, self/translation between two "dominating" literatures; second, self/translation between two "dominated" literatures; and third, self/translation between the "dominated" and the "dominating" literatures. In this latter case, using Grutman's terminology (2013b), diglossia precludes the possibility of creating "horizontal exchanges" between languages of potentially equal status or prestige; rather, it encourages bilingual writers to self-translate "vertically" - and whenever self-translation happens between languages/literatures of disparate status, author-translators can either self-translate uphill (into the "dominating" literature and prestigious language of the State to which they officially belong) or downhill (into the "dominated" literature and non-prestigious language, which is most often their mother tongue) (Grutman 2013a, 230). The way diglossia materialises in vertical self-translation varies. In multilingual Spain the tendency is for the official non-state languages to go uphill: i.e. those committed writers creating in Catalan, Galician or Basque - or non-recognised languages such as Asturian or Aragonese - as part of the struggle against the imposed (neo)colonial power, do self-translate into Castilian Spanish later. However, in 
Castro, Olga, Sergi Mainer and Svetlana Page. 2017. Introduction: Self-Translating, from Minorisation to Empowerment. In Self-Translation and Power: Negotiating Identities in Multilingual European Contexts, ed. Olga Castro, Sergi Mainer and Svetlana Page, 1-22. London: Palgrave.

multilingual Italy (with one official language only and the lack of recognition of the regional languages) the tendency is the opposite, and self-translators there tend to produce first versions in the dominant national language before rendering them downhill into a dialect or regional language.

For native literary self-translators who live and work in a diglossic society characterised by a sociolinguistic conflict between the self-translator's working languages, individual decisions become laden with political consequences. The process of negotiation within self-translation becomes complex and dependent upon the conditions of the venture. When operating within an unequal pair of languages, such as a local minority language and a hegemonic language, self-translators are encountering problems with negotiation of various sides of their "self" translated through different linguistic media. Thus, when Kozovoï, a Soviet Russian writer used to his poetry being appreciated, begins to translate himself into French, he encounters a strong resistance of the target polysystem (see Holter). In combating this, he unwillingly adopts a more familiar lens for his works and gains some recognition as a dissident, if not as a poet. What we observe here is an expatriated author who finds himself in another hegemonic language position. In a different situation, when it is a minorised language which is being selftranslated into a hegemonic one, writers are often faced with self-editing which can stretch from omitted words or substitute phrases to rewritten passages, as exemplified in the case of Halide Edib's rewriting of The Turkish Ordeal, also explored in this volume (see Ozdemir). We define the cases of self-rewriting motivated by ideological or political reasons as "self-censorship," 
Castro, Olga, Sergi Mainer and Svetlana Page. 2017. Introduction: Self-Translating, from Minorisation to Empowerment. In Self-Translation and Power: Negotiating Identities in Multilingual European Contexts, ed. Olga Castro, Sergi Mainer and Svetlana Page, 1-22. London: Palgrave.

introducing a term we consider vital to self-translation studies to account for the situations where self-translators face the dilemma of self-editing themselves before they even begin translating. Depending on the degree of self-censorship, the self-translator may foresee the problematic metonymies of the translation process and discuss them with the editors, funders or censors, thus the negotiation of self-translation issues can occasionally start even before the commissioning of translation is discussed.

As negotiation in the translation process comes to the forefront in research and media, it necessarily raises the issue of the function of the translator's agency, a subject which has witnessed one of the most significant shifts of attention in translation studies. Yet, despite the number of works published with case studies on individual self-translators, the agency of the self-translator as a powerful mediator has not been sufficiently examined. This is a gap that this collection is now addressing.

\section{What is Special about Self-Translation?}

Although many publications have placed power at the centre of debate in translation studies yielding fruitful academic outcomes, very few scholarly contributions have explicitly examined the crucial connection between power relations and self-translation. The marginality of self-translation within the field of translation studies until recently may explain this research gap. Rainier Grutman's entry to the first edition of the Routledge Encyclopedia of Translation Studies (1998) publicly condemned that marginality, declaring 
Castro, Olga, Sergi Mainer and Svetlana Page. 2017. Introduction: Self-Translating, from Minorisation to Empowerment. In Self-Translation and Power: Negotiating Identities in Multilingual European Contexts, ed. Olga Castro, Sergi Mainer and Svetlana Page, 1-22. London: Palgrave.

self-translation to be an invisible topic in translation studies, probably due to the monolingual agenda of much critical writing about "national" literatures. Another reason probably leading to its neglected status, according to Grutman, was the misconception of self-translation as a rarity only practised by bilingual writers from major literatures, such as Samuel Beckett, Jorge Luis Borges, Vladimir Nabokov or Rabindranath Tagore. In The Bilingual Text: History and Theory of Literary Self-Translation (2007), the first monograph on self-translation ever published in English, Jan Hokenson and Marcella Munson explored the same idea when trying to explain the peripherality of self-translation: its perception as a practice favoured by writers seen as "idiosyncratic anomalies, mostly preening polyglots or maladaptive immigrants" $(2007,1)$. Contrary to this misconception, the revised and updated version of the "self-translation" entry in the same encyclopedia, published by Grutman nine years later (2009), shows how much the topic has evolved since then, and the same author concludes in a more recent publication: "self-translation is neither an exceptional nor a particularly recent phenomenon. In today's world, there are probably writers translating themselves on every inhabited continent, with some areas buzzing with activity" (Grutman 2013a, 189). However, it is not only in today's world, as Hokenson and Munson demonstrate that the practice of self-translation can be traced back to the Middle Ages and has been continuous up to the new millennium. True, it has frequently been practised "on the quiet." It is only in recent times, due to growing multilingualism of contemporary societies and the internationalisation of English, that the frequent and recurrent practice of 
Castro, Olga, Sergi Mainer and Svetlana Page. 2017. Introduction: Self-Translating, from Minorisation to Empowerment. In Self-Translation and Power: Negotiating Identities in Multilingual European Contexts, ed. Olga Castro, Sergi Mainer and Svetlana Page, 1-22. London: Palgrave.

self-translation has become more visible through a process of "coming out." Consequently, more scholarly attention is being paid to self-translation, as more and more bilingual authors self-translate, gaining access to other literary fields where they can acquire monetary, cultural and symbolic capital.

As a result of this growing interest, in the last few years the number of publications devoted to examining the particularities of self-translation has experienced a remarkable growth, ${ }^{1}$ to the extent that the label "self-translation studies" has been recently coined by Simona Anselmi (2012) in her monograph On Self-translation: An Exploration in Self-Translators' Teloi and Strategies, to underline the distinctiveness of the field. One of the most remarkable features is, in our view, the innovative perspectives it offers to the study of power, more specifically in the current multilingual European context. As this current volume will later demonstrate, the conceptualisation of power in self-translation is intimately connected with the tensions generated by geopolitical spaces where major and minorised cultures and nations collide, and a constant struggle for hegemony is met by different forms of resistance.

In close relation to this, a second distinctive feature that emerges when conceptualising power in self-translation is that of the "in-between" place of the self-translator. Given that self-translation occurs in multilingual contexts defined by asymmetrical relations between languages, literatures and cultures, "the practice of self-translation is never innocent" (Whyte 2002, 64). Whenever bilingual writers decide to self-translate their own words into another language in which they are competent, they nearly always play a double role as authors and translators affiliated to two different and often 
Castro, Olga, Sergi Mainer and Svetlana Page. 2017. Introduction: Self-Translating, from Minorisation to Empowerment. In Self-Translation and Power: Negotiating Identities in Multilingual European Contexts, ed. Olga Castro, Sergi Mainer and Svetlana Page, 1-22. London: Palgrave.

competing literary systems. Self-translators' double affiliation in multilingual contexts places them in a privileged position to problematise power and to negotiate identities. That is, the centrality of power in self-translation studies involves acknowledging the author-translator's privileged position to negotiate the experiences of the subaltern and colonised and to scrutinise conflicting minorised vs. hegemonic cultural identities. Yet, this is not an easy task, for "wherever hierarchies in languages and literatures are outspoken, multilingual writers and self-translators risk having a hard life" (Meylaerts 2011). Regardless of the language/literary system chosen for their texts to be first published, a series of ideological tensions affecting notions of hegemony and national/territorial identity are likely to emerge, for "while national identities can be negotiated in a variety of ways, current research privileges language and literary policies as increasingly important means of social control which allow nation-states to define who is in and who is out" (Blackledge 2005, 42). These tensions will not be avoided by having their works simultaneously published in both languages, as the power differential between the languages would still manifest, originating as internal frictions and mediations. Indeed, the use of self-translation as a form of resistance may also contribute to situations of unconscious self-minorisation or the "failure" of self-translation, as expressed in this volume (see Ramis).

Invisibility in the practice of self-translation plays a decisive role in this self-minorisation process, and the degree of (in)visibility may be related to different factors. Among them, the author-translator's own decision to present their second text as an original, possibly to try to get access to a second 
Castro, Olga, Sergi Mainer and Svetlana Page. 2017. Introduction: Self-Translating, from Minorisation to Empowerment. In Self-Translation and Power: Negotiating Identities in Multilingual European Contexts, ed. Olga Castro, Sergi Mainer and Svetlana Page, 1-22. London: Palgrave.

literary community, in what Xosé Manuel (2011) has termed as "opaque selftranslation." However, even when minorised language writers self-translating into a dominant language want to be transparent, making their first language visible as part of their identity, the publisher may present their self-translation as a first original if they consider the book is going to sell better. (In)visibility may also be related to patterns of collaboration between different agents, as exemplified in this collection with the writer/spouse and writer/editor pairs (see Manterola), also in a "minority" context. In sum, self-translation as a practice to promote minorised cultures and nations may come into question.

A third crucial aspect to the extraordinary significance of power in selftranslation is that the negotiations inherent in this type of mediation undermine some of the traditional translation studies' axioms and dichotomies. By its own very nature, self-translation destabilises the typical hierarchical relation between the original and the translation, between the author, and the translator, "since the bilingual text exists in two language systems simultaneously, the monolingual categories of author and original can no longer be maintained" (Hokenson and Munson 2007, 2). These are problematic dichotomies, regardless of any conventional definitions they may have been assigned in "translation proper." As Anthony Cordingley aptly states in his introduction to Self-Translation: Brokering Originality in Hybrid Culture (2013a), the bilingual oeuvre and the experience of the self-translator pose challenges to them. A self-translation occurs when a writer (re)creates a work in more than one language, and therefore it "typically produces another 'version' or a new 'original' of a text" (Cordingley 2013b, 2). In fact, in his 
Castro, Olga, Sergi Mainer and Svetlana Page. 2017. Introduction: Self-Translating, from Minorisation to Empowerment. In Self-Translation and Power: Negotiating Identities in Multilingual European Contexts, ed. Olga Castro, Sergi Mainer and Svetlana Page, 1-22. London: Palgrave.

keynote address given at the Self-Translation in the Iberian Peninsula conference held in Cork, Ireland, in 2013, the Basque writer and selftranslator Unai Elorriaga (2013) did not regard his self-translations as such, but as later versions of the same text even if the language in which they were written was a different one. As a consequence, the self-translated text is often called a second-original: "A self-translated text is a second original rendered into a second language with all the liberty an author always enjoys (but never a translator). An original that has the benefit of authorial intentionality, according to Brian T. Fitch $(1988,125)$, sometimes denied to versions made by other translators" (Santoyo 2013, 28). From an opposite perspective, at the same conference the Galician writer and professional translator María Reimóndez (2013) discussed her self-translation experience rendering one of her novels into Castilian Spanish. She argued that what she produced was indeed a different text for a different audience, mediated by her own ideology and motivations as a translator, and not only as "the" author. Quite significantly, the self-translation visibly shows Reimóndez as author of the Galician novel and as translator of the second text in Castilian Spanish. ${ }^{2}$ This notion of the self-translation as a new and different text allows for a move against invisibility to promote languages or cultures in precarious (or potentially precarious) situations.

A number of conclusions can be drawn from this discussion. Firstly, the notion of source text and target text becomes completely blurred, as the selftranslated text cannot be studied in terms of equivalence, loyalty or adequacy to another text previously written. The self-translated text is a translation, but 
Castro, Olga, Sergi Mainer and Svetlana Page. 2017. Introduction: Self-Translating, from Minorisation to Empowerment. In Self-Translation and Power: Negotiating Identities in Multilingual European Contexts, ed. Olga Castro, Sergi Mainer and Svetlana Page, 1-22. London: Palgrave.

a very special one, defined by hybridity. Secondly, the self-translator is at once author and translator, and her/his "authority" over both the first text and the second original is never questioned. Questions such as "who authors translations and who authorises them?" (Woods 2016, 2), commonly asked in literary translation studies, become irrelevant. The self-translator, being the author, escapes the precarious position of Lawrence Venuti's “invisible" scribe (1995) and her/his production receives instant validation of it being an authorised translation. Thirdly, as rewriter of an existing text, the selftranslator is freer to alter the text beyond the restrictions a professional translator will be limited by. Self-translation should be approached from a similar but subtly different perspective from a non-author's translation, whereby the author's shifting personal affiliations throughout time need to be taken into account. Navigating between an attitude of attraction towards the self-translation and an attitude of refusal to be translated, as we have already argued, there will be cases when author-translators choose to emphasise power hierarchies (being "author" twice, making translation absolutely invisible and presenting it as an original), while in other cases they use the "self" element to subvert that hierarchy. This undoubtedly problematises the difficult position in which self-translators (especially those from minorised languages) find themselves.

Power as a category is inherent in self-translation. The shifting dynamics of our (multilingual) times invite us to crucially empower selftranslation: by questioning some of the core facets of translation studies, selftranslation offers not only a powerful tool for their deconstruction but also 
Castro, Olga, Sergi Mainer and Svetlana Page. 2017. Introduction: Self-Translating, from Minorisation to

Empowerment. In Self-Translation and Power: Negotiating Identities in Multilingual European Contexts, ed. Olga Castro, Sergi Mainer and Svetlana Page, 1-22. London: Palgrave.

provides some productive possibilities into further research into multilingualism in action, translators' activism and translation as regular human activity. It is here where the power of self-translation lies.

\section{Organisation of the Book}

The eleven chapters included in this book investigate power relations with respect to the political, social, cultural and economic implications of selftranslation in different multilingual spaces in Europe - namely Arabic, Basque, Catalan, Dutch, English, French, Italian, Ladino, Occitan, Russian, Spanish, Swiss German and Turkish. Focusing on these European contexts, and engaging with the power turn in translation studies, the volume offers innovative perspectives on the role of self-translators as cultural and ideological mediators situated in a privileged position to challenge power, to negotiate conflicting minorised vs. hegemonic cultural identities. These articles offer an interdisciplinary and multidisciplinary approach to power, stemming from a variety of methods in different chapters, which provide new perspectives on the author's self-representation and on questions of personal, cultural, linguistic and national identities. By investigating the textual and contextual aspects conditioning the writing, production and reception of a selftranslation, this interdisciplinary approach also provides a qualitative investigation into the power/translation/self-identity triad, which has been common in postcolonial and poststructuralist translation approaches.

The book is divided into three parts: 
Castro, Olga, Sergi Mainer and Svetlana Page. 2017. Introduction: Self-Translating, from Minorisation to

Empowerment. In Self-Translation and Power: Negotiating Identities in Multilingual European Contexts, ed. Olga Castro, Sergi Mainer and Svetlana Page, 1-22. London: Palgrave.

I. Hegemony and Resistance.

II. Self-Minorisation and Self-Censorship.

III. Hybridisation, Collaboration and Invisibility.

The chapters in part I explore one of the fundamental aspects linking selftranslation to power, i.e. the struggle for recognition of minorised cultures in preference to hegemonic ones in literary texts. The three chapters comprising the first part examine the power relations and problems dealing with hegemony, resistance and activism through self-translation and the strategies developed by self-translators. They elucidate the ways self-translators confront situations of diglossia and linguistic/cultural marginalisation. The case studies gathered here provide an array of historical and current contexts and translation studies methodologies in self-translation unified by two main notions of power and self-translation.

Firstly, Rainier Grutman in his chapter "Babel in (spite of) Belgium: Patterns of Self-Translation in a Bilingual Country" explores the way in which the fluctuating political situations in Belgium since its independence in 1831 have either helped to promote or limit self-translation. From the Second World War until today, both linguistic communities, the French and the Flemish, have been drawn apart, each of them preferring to compose literature in their own language. As a result, self-translation has been mostly left aside. Then, Christian Lagarde analyses self-translation between Occitan and French, concentrating on four major authors: René/Renat Nelli, Max Rouquette/Roqueta, Jean Boudou/Joan Bodon and Robert Lafont. In his "The 
Castro, Olga, Sergi Mainer and Svetlana Page. 2017. Introduction: Self-Translating, from Minorisation to Empowerment. In Self-Translation and Power: Negotiating Identities in Multilingual European Contexts, ed. Olga Castro, Sergi Mainer and Svetlana Page, 1-22. London: Palgrave.

Three Powers of Self-Translating or Not Self-Translating: The Case of Contemporary Occitan Literature (1950-1980)," Lagarde argues that these authors took different approaches to translation, self-translation and nontranslation. Their choices were motivated by the influence of three Powers. The first, the diglossic power exerted by the French literary field over the Occitan Arts. The second, the power from within the community of Occitan authors to define a set of rules by which they would agree to work. The third is the power of the authors to decide for themselves their own individual behaviour. Finally, in her chapter "Self-Translation as Testimony: Halide Edib Rewrites The Turkish Ordeal," Mehtap Ozdemir discusses self-translation from the point of view of textual and lingual migration. Edib's self-translation of her memoirs addresses issues of self-representation and national history as re-written for different audiences in English and in Turkish. Her self-translation method is also an excellent illustration of productive self-censorship.

Self-censorship is precisely one of the notions discussed in part II, together with what we have termed as self-minorisation. Both self-censorship and self-minorisation are conceptualised as problematic issues for selftranslation. The chapters in this part aim to investigate the challenges of selftranslation whenever they may lead to counterproductive processes in different geopolitical contexts, in what could be termed as practices of "unintentional self-minorisation." Indeed, self-translation can be regarded as a productive tool to promote minorised cultures in the wider geopolitical context through the usage of a hegemonic language. However, this may ultimately have negative implications, as the use of a hegemonic language in self- 
Castro, Olga, Sergi Mainer and Svetlana Page. 2017. Introduction: Self-Translating, from Minorisation to Empowerment. In Self-Translation and Power: Negotiating Identities in Multilingual European Contexts, ed. Olga Castro, Sergi Mainer and Svetlana Page, 1-22. London: Palgrave.

translation can (inevitably) lead to a process of unintentional self-minorisation and further invisibility, undermining the self-translator's initial goal of promoting their minorised culture. This may have even further consequences if we bear in mind that the self-translated/hegemonic text is generally used as the source text deployed in a translation into a third language. By examining these power inequalities from different theoretical approaches, the chapters included here discuss precisely what the risks of self-translation may be and how these self-minorising practices are characterised, more often than not closely linked to practices of self-censorship. For example, processes of selftranslation occurring before the text is published or processes of "invisible" self-translation may function as productive self-minorising and self-censoring strategies to conceal the (self-)translated nature of the target text.

One innovative and fruitful approach to the dyad self-minorisation/selfcensorship is offered by Josep Miquel Ramis in his chapter "The Failure of Self-Translation in Catalan titerature." Ramis examines the generally unidirectional status of self-translation in Catalan, where a considerable number of Catalan writers are asked to self-translate into Spanish, while Catalan authors writing in Spanish hardly ever self-translate into Catalan. Instead, professional translators undertake this task. As a consequence, Catalan self-translation unwittingly contributes to the self-minorisation of Catalan literature. Ramis concludes that whilst there is still time left to reverse this situation, it is limited and reaching the point of crisis. The next chapter is Arzu Akbatur's "The Power and Burden of Self-Translation: Representation of "Turkish Identity" in Elif Shafak's The Bastard of Istanbul," in which the 
Castro, Olga, Sergi Mainer and Svetlana Page. 2017. Introduction: Self-Translating, from Minorisation to Empowerment. In Self-Translation and Power: Negotiating Identities in Multilingual European Contexts, ed. Olga Castro, Sergi Mainer and Svetlana Page, 1-22. London: Palgrave.

author assesses the complex interconnections within the triad power/national identity/self-translation. Indeed, the controversies of Shafak's The Bastard of Istanbul (2007) led its author to be tried under the Turkish Penal Code. In her self-translation, Shafak's "interventionist" and "trans/formative" strategies serve to recontextualise the novel to different audiences. This reconstruction of identity and culture and the writer's "burden of translation" have a selfminorising effect. In his contribution entitled "Self-translation and Linguistic Reappropriation: Juan Gelman's dibaxu," Brandon Rigby deals with Ladino, a language derived from Spanish and spoken by the Sephardic Jews who were expelled from the Iberian Peninsula. Ladino is employed as a symbol of resistance in a displaced political and linguistic space during the Dirty War in Argentina (1974-83). Rigby argues the Argentinian poet Juan Gelman's use of Ladino in his bilingual edition of dibaxu functions both as an act of selfminorisation and as a way to detach himself from the dominant language of the dictatorship, creating an alternative - and resistant - identity. This part finishes with Harriet Hulme's "Self-Translating between Minor and Major Languages: A Hospitable Approach in Bernardo Atxaga's Obabakoak." Atxaga first wrote this collection of short stories in Basque. Its self-translation into Spanish was a rewriting process, which entailed numerous structural and thematic changes. Engaging with Lawrence Venuti's ideas, Hulme contends that Obabakoak is placed in the discursive context of the tensions between the demands of the "domestic" and the "foreign." Such tensions in selftranslation are solved "hospitably," generating a locus of cultural and linguistic transformation. 
Castro, Olga, Sergi Mainer and Svetlana Page. 2017. Introduction: Self-Translating, from Minorisation to

Empowerment. In Self-Translation and Power: Negotiating Identities in Multilingual European Contexts, ed. Olga Castro, Sergi Mainer and Svetlana Page, 1-22. London: Palgrave.

The final part deals with three of the most problematic challenges of self-translation: collaboration, hybridisation and invisibility. It discusses how the process of self-translation, when undertaken prior to the publication of a text, may transform its ideological and formal nature. This self-translation may involve some form of collaboration, whenever the author-translator is rewriting their source text with someone else's assistance due to their lack of proficiency in the target language, or simply their willingness to incorporate somebody else in the process so as to add a new layer of meaning to the resulting text. With or without collaboration, the process of linguistic hybridisation inherent to self-translation destabilises conceptions of fixed national and individual identities.

It opens with Elizabete Manterola Agirrezabalaga's "Collaborative Self-Translation in a Minority Language: Power Implications in the Process, the Actors and the Literary Systems Involved." Taking Basque literature as an example, Manterola Agirrezabalaga discusses the phenomenon of collaborative self-translation, which has received very little scholarly attention so far. As well as considering the role played by the different translators involved in the collaborative process, the author also takes into account the existing power relations between hegemonic and minorised cultures and languages. Next, Julia Holter examines another example in which collaborative self-translation takes place. In her chapter "Collaborative SelfTranslation as a Catastrophe: The Case of Vadim Kozovoï in French," she contemplates the case of the dissident Russian poet and translator Vadim Kozovoï and the way in which he self-translated his poems into French aided 
Castro, Olga, Sergi Mainer and Svetlana Page. 2017. Introduction: Self-Translating, from Minorisation to Empowerment. In Self-Translation and Power: Negotiating Identities in Multilingual European Contexts, ed. Olga Castro, Sergi Mainer and Svetlana Page, 1-22. London: Palgrave.

by distinguished French literary figures. Yet, while the existing political situation eased the promotion of a Russian dissident in the French literary world, the dominant literary poetics of French meant that he did not receive the acclaim he had hoped for. In the third chapter of the part, Rita Wilson centres on Amara Lakhous' translingual writing understood as self-translation. Her chapter "Beyond Self-Translation: Amara Lakhous and Translingual Writing as Case Study" investigates Lakhous' novels, written in Italian and Arabic, and how his translingual writing becomes a redefinition of the self. In this way, self-translation becomes a liberating and empowering act. Wilson also situates Lakhous' work in the current migratory climate and claims that this kind of writing undermines preconceived notions of cultural and national identities. The final chapter of the part, and of the whole collection, is Marc Cesar Rickenbach's “Writing Beyond the Border: Max Frisch, Dialect and Place in Swiss-German Literature." Rickenbach analyses the problems of Swiss German literature and self-translation through the case study of Max Frisch. Self-translation is regarded both as an act that takes place while writing the text and as a process of "deterritorialisation" that problematises state and regional boundaries in literature. The socio-political positioning of the author plays a key role in different German-speaking areas.

The three themes, discussed from a variety of perspectives and multiple languages, present a wide tapestry of European multilingualisms represented through the medium of self-translation. Despite its inevitable omissions, we are confident that this volume crucially contributes to expanding the 
Castro, Olga, Sergi Mainer and Svetlana Page. 2017. Introduction: Self-Translating, from Minorisation to Empowerment. In Self-Translation and Power: Negotiating Identities in Multilingual European Contexts, ed. Olga Castro, Sergi Mainer and Svetlana Page, 1-22. London: Palgrave.

epistemological, theoretical, methodological, practical and geopolitical dimensions of self-translation, also encouraging further innovations in the field.

\section{References}

Anselmi, Simona. 2012. On Self-translation: An Exploration in SelfTranslators' Teloi and Strategies. Milan: LED Edizioni Universitarie.

Álvarez, Román and África Vidal, eds. 1996a. Translation, Power, Subversion, Clevedon: Multilingual Matters.

---. 1996b. Translating: A Political Act. In Translation, Power, Subversion, eds. Román Álvarez and África Vidal, 1-9. Clevedon: Multilingual Matters.

Bassnett, Susan. 1998. The Translation Turn in Cultural Studies. In Constructing Cultures: Essays on Literary Translation, eds. Susan Bassnett and André Lefevere, 123-140. Clevedon: Multilingual Matters.

---. 1996. The Meek or the Mighty: Reappraising the Role of the Translator. In Translation, Power, Subversion, eds. Román Álvarez and África Vidal, 10-24. Clevedon: Multilingual Matters.

Bassnett, Susan, and André Lefevere, eds. 1990. Translation, History and Culture. London: Pinter Publishers.

Blackledge, Adrian. 2005. Discourse and Power in a Multilingual World. Amsterdam: Benjamins.

Casanova, Pascale. 1999. La République mondiale des Lettres. Paris: Éditions du Seuil.

Cordingley, Anthony, ed. 2013a. Self-Translation: Brokering Originality in Hybrid Culture. London: Bloomsbury Publishing.

Cordingley, Anthony. 2013b. Introduction: Self-translation, going global. In Self-Translation: Brokering Originality in Hybrid Culture, 1-10. London: Bloomsbury Publishing. 
Castro, Olga, Sergi Mainer and Svetlana Page. 2017. Introduction: Self-Translating, from Minorisation to Empowerment. In Self-Translation and Power: Negotiating Identities in Multilingual European Contexts, ed. Olga Castro, Sergi Mainer and Svetlana Page, 1-22. London: Palgrave.

Cronin, Michael. 1995. Altered States: Translation and Minority Languages. TTR 8(1): 85-103.

Cronin, Michael. 2003. Translation and Globalization. London: Routledge.

Dasilva, Xosé Manuel. 2011. La autotraducción transparente y la autotraducción opaca. In Aproximaciones a la autotraducción, eds. Xosé Manuel Dasilva and Helena Tanqueiro, 45-68. Vigo: Editorial Academia del Hispanismo.

Deleuze, Gilles and Félix Guatari. 1986. Kafta. Toward a Minor Literature. Transl. Dana Polan. Minnesota: University of Minnesota Press.

Díaz Fouces, Óscar. 2005. Translation policy for minority languages in the European Union. Globalisation and Resistance. In Less Translated Languages, eds. Albert Branchadell and Lovell Margaret West, 95-104. Amsterdam: Benjamins.

Ďurišin, Dionyz. 1984. Les communautés interlittéraires spécifiques. Bratislava: Veda.

Elorriaga, Unai. 2013. El singular oficio de la autotraducción. Keynote address at the "Self-Translation in the Iberian Peninsula" conference, Coláiste na hOllscoile Corcaigh/University College Cork, Cork, Ireland, 20-21 September 2013.

Even-Zohar, Itamar. 1990. Polysystem Studies. Poetics Today 11(1): 45-51.

Even-Zohar, Itamar. 1978. The Position of Translated Literature within the Literary Polysystem. In Literature and Translation: New Perspectives in Literary Studies, eds. James S Holmes, José Lambert and Raymond van den Broeck, 117-127. Leuven: Acco.

Fitch, Brian T. 1988. Beckett and Babel: An Investigation into the Status of the Bilingual. Toronto: Toronto University Press.

Foucault, Michel. 1976. Histoire de la sexualité I: La volonté de savoir. Paris: Gallimard.

Foucault, Michel. 1995. Discipline and Punish: The Birth of the Prison. Trans. Alan Sheridan. New York: Vintage Books.

Gentes, Eva. 2017. Bibliography: Autotraduzione / autotradución / selftranslation. (27th update, 1 January 2017) http://self- 
Castro, Olga, Sergi Mainer and Svetlana Page. 2017. Introduction: Self-Translating, from Minorisation to Empowerment. In Self-Translation and Power: Negotiating Identities in Multilingual European Contexts, ed. Olga Castro, Sergi Mainer and Svetlana Page, 1-22. London: Palgrave.

translation.blogspot.co.uk/2017/01/update-bibliography-on-self-

translation.html (accessed 3 January 2017).

Gentzler, Edwin. 2002. Translation, Poststructuralism and Power. In Translation and Power, eds. Maria Tymoczko and Edwin Gentzler, 195-218. Boston and Amherst: University of Massachusetts Press.

Gentzler, Edwin and Maria Tymoczko. 2002. Introduction. In Translation and Power, eds. Maria Tymoczko and Edwin Gentzler, xi-xxviii. Boston and Amherst: University of Massachusetts Press.

Grutman, Rainier. 2013a. Beckett and Beyond. Putting Self-Translation in Perspective. Orbis Litterarum, 68(3): 188-206.

---. 2013b. A Sociological Glance at Self-Translation and Self-Translators. In Self-Translation. In Brokering Originality in Hybrid Culture, ed. Anthony Cordingley, 63-80. London and New York: Bloomsbury Academic.

---.2009. Self-translation. In Routledge Encyclopedia of Translation

Studies, 2nd edition, eds. Mona Baker and Gabriela Saldanha, 257-260. London and New York: Routledge.

---. 1998. Auto-translation. In Encyclopedia of Translation Studies, ed. Mona Baker, 17-20. London and New York: Routledge.

Hermans, Theo. 1999. Translation in Systems: Descriptive and SystemOriented Approaches Explained. Manchester: St. Jerome Publishing.

Hokenson, Jan Walsh and Marcella Munson, 2007. The Bilingual Text: History and Theory of Literary Self-Translation. Abington and New York: Routledge.

Lefevere, André. 1992. Translation, Rewriting and the Manipulation of Literary Fame. London and New York: Routledge.

Meylaerts, Reine. 2011. Multilingual writers: a blind spot in Translation Studies. http://paratraduccion.com/index.php/web-tv/pildoras.html (accessed 7 December 2015).

mTm: minor Translating major - major Translating minor. http://www.mtmjournal.gr/ (accessed 12 March 2015).

Patrick, Donna. 2010. Language Dominance and Minorization. In Society and Language Use, eds. Jan-Ola Ösma and Jef Verschueren, 166-191. Amsterdam: John Benjamins. 
Castro, Olga, Sergi Mainer and Svetlana Page. 2017. Introduction: Self-Translating, from Minorisation to Empowerment. In Self-Translation and Power: Negotiating Identities in Multilingual European Contexts, ed. Olga Castro, Sergi Mainer and Svetlana Page, 1-22. London: Palgrave.

Santoyo, Julio César. 2013. On Mirrors, Dynamics and Self-Translations. In Self-Translation. Brokering Originality in Hybrid Culture, ed. Anthony Cordingley, 27-38. London and New York: Bloomsbury Academic.

Reimóndez, María. 2013. (Self)Translation and Phagocytising: From Exotic Flavours to Programmed Indigestion. Paper presented at the "Self-Translation in the Iberian Peninsula" conference, Coláiste na hOllscoile Corcaigh/University College Cork, Cork, Ireland, 20-21 September 2013.

Tymoczko, Maria and Edwin Gentzler, eds. 2002. Translation and Power. Amherst and Boston: University of Massachusetts Press.

Venuti, Lawrence. 1995. The Translator's Invisibility: A History of Translation. London and New York: Routledge.

Wallerstein, Immanuel. 2004. World-Systems Analysis: An Introduction. Durham, North Carolina: Duke University Press.

---. 1974. The Modern World-System I. New York: Academic Press.

Warwick Research Collective. 2015. Combined and Uneven Development: Towards a New Theory of World-Literature. Liverpool: Liverpool University Press.

Whyte, Christopher. 2002. Against Self-translation. Translation and Literature 11(1): 64-71.

Woods, Michelle. 2016. Introduction. In Authorizing Translation, ed. Michelle Woods, 1-11. Abingdon and New York: Routledge and IATIS.

Yurchuk, Olena. 2013. Some Comments Concerning Ukrainian Postcolonial Studies. Slavia Occidentalis 70(2): 147-155.

\footnotetext{
${ }^{1}$ A regularly updated online bibliography on self-translation is available on Eva Gentes's blog www.self-translation.blogspot.com with the title "Bibliography: Autotraduzione / autotradución / selftranslation." The $27^{\text {th }}$ edition of this bibliography was published on 1 January 2017 , and includes special issues, edited volumes, book chapters, journal articles, $\mathrm{PhD}$ thesis, MA dissertations, BA dissertations and unpublished conference presentations (see Gentes 2017).

${ }^{2}$ In any case, it seems likely that these "visible" self-translation strategies are available to her as author of the first text, whereas it would be much more difficult to put them in practice if she were merely a translator proper.
} 